\title{
Biogeography and community structure of abyssal scavenging Amphipoda (Crustacea) in the Pacific Ocean
}

\author{
Tasnim Patel ${ }^{1,2}$, Henri Robert ${ }^{1}$, Cedric D’Udekem D’Acoz ${ }^{3}$, Koen Martens ${ }^{1,2}$, Ilse De Mesel ${ }^{1}$, Steven Degraer ${ }^{1,2}$, and \\ Isa Schön ${ }^{1,4}$ \\ ${ }^{1}$ Operational Directorate Natural Environment, Aquatic and Terrestrial Ecology, Royal Belgian Institute of Natural Sciences, \\ Vautierstraat 29, 1000 Brussels, Belgium \\ ${ }^{2}$ Department of Biology, University of Ghent, K.L. Ledeganckstraat 35, 9000 Ghent, Belgium \\ ${ }^{3}$ Operational Directorate Taxonomy \& Phylogeny, Royal Belgian Institute of Natural Sciences, Vautierstraat 29, \\ 1000 Brussels, Belgium \\ ${ }^{4}$ Research Group Zoology, University of Hasselt, Agoralaan Building D, 3590 Diepenbeek, Belgium
}

Correspondence: Tasnim Patel (tpatel@naturalsciences.be)

Received: 18 July 2018 - Discussion started: 7 August 2018

Revised: 15 June 2019 - Accepted: 1 July 2019 - Published: 20 May 2020

\begin{abstract}
In 2015, we collected more than 60000 scavenging amphipod specimens during two expeditions to the Clarion-Clipperton fracture zone (CCZ) in the Northeast (NE) Pacific and to the DISturbance and re-COLonisation (DisCOL) experimental area (DEA), a simulated mining impact disturbance proxy in the Peru Basin in the Southeast (SE) Pacific. Here, we compare biodiversity patterns of the larger specimens $(>15 \mathrm{~mm}$ ) within and between these two oceanic basins. Eight scavenging amphipod species are shared between these two areas, thus indicating connectivity. Overall diversity was lower in the DEA (Simpson index, $D=0.62)$, when compared to the CCZ $(D=0.73)$, and particularly low at the disturbance site in the DEA and the site geographically closest to it. Local differences within each basin were observed too. The community compositions of the two basins differ, as evidenced by a non-metric dimensional scaling (NMDS) analysis of beta biodiversity. Finally, a single species, Abyssorchomene gerulicorbis (Schulenberger and Barnard, 1976), dominates the DEA with $60 \%$ of all individuals.
\end{abstract}

\section{Introduction}

The abyssal deep sea $(3000-6000 \mathrm{~m})$ represents the largest ecosystem on the planet, with the abyssal seafloor covering approximately $54 \%$ of the Earth's solid surface (Gage and Tyler, 1991; Rex et al., 1993). Since it is one of the least investigated ecosystems, there are still extensive gaps in our knowledge of deep-sea fauna (German et al., 2011). Marine research has thus far focused on coastal areas, hydrothermal vents or chemosynthetic habitats, whereas openocean abyssal plains have been less extensively investigated (Ramirez-Llodra et al., 2010). This is unsurprising given the challenges of sampling this remote environment, which is impeded by several confounding factors. For example, deepsea sampling is both financially expensive and labour intensive and, furthermore, constrained by the challenge of deploying equipment at low temperatures $\left(0.01-4.0^{\circ} \mathrm{C}\right)$ and at high hydrostatic pressures (Sweetman et al., 2017). Therefore, to date very little of the deep sea has been sampled and the oversampling in the North Atlantic basin has created a biased knowledge base (McClain and Hardy, 2010). Consequently, owing to the low availability of data about deepsea biodiversity, combined with the inherent risk of undersampling, it is difficult to estimate species richness in the deep sea.

In the traditional view of the deep sea, the abyss was considered to be homogeneous and many species were thought to have large biogeographical ranges, their dispersal aided by an apparent lack of barriers (Sanders, 1968). This hypothesis was challenged by the discovery of chemosynthetic habitats, e.g. hydrothermal vents (Lonsdale, 1977), cold seeps (Paull et al., 1984), seasonal fluctuations in primary productivity 
(Billett et al., 1983) and erratic whale falls (Smith et al., 1989). All of this research has demonstrated that the deep sea is a heterogeneous environment and is controlled by many factors, including particulate organic carbon (POC) flux, water depth, flow regime, current circulation, seafloor topography (Laver et al., 1985) and also historical factors, e.g. the opening of ocean basins (i.e. rifting), sea level rise and fall, and periods of deep-sea anoxia (Smith et al., 2006). All of these can result in a mosaic of different communities (Levin et al., 2001), many of which do not follow a latitudinal gradient (Brandt et al., 2007).

It has also been established that dispersal ability of species on the one hand, and their actual geographic and bathymetric distribution range on the other hand, are not always linked and are often dependent on habitat suitability, fragmentation and ecological flexibility (Lester et al., 2007; Liow, 2007). Therefore, although the deep seafloor includes some of the largest contiguous features on the planet, the populations of many deep-sea species are spatially fragmented and may become increasingly so with continued human disturbance (Hilário et al., 2015).

In the last decade, there has been a higher demand for exploitation of deep-sea resources, e.g. rare-earth element (REE) extraction (such as those concentrated in manganese nodule provinces) (Ramirez-Llodra et al., 2011). As a result, ecologists are increasingly asked to assess the ecological risks of these mining activities and to provide sustainable solutions for its mitigation, in order to prevent adverse changes to the deep-sea ecosystem (International Seabed Authority, 2017).

Glover et al. (2001) showed that abyssal sediments can contain high biodiversity, with more than 100 species of meiofaunal invertebrates (e.g. nematodes, copepods) and protists (e.g. foraminifers) found every square metre. Despite this, our knowledge of the deep-sea ecosystem structure and functioning is still limited, and there is a paucity of data about the distribution, drivers and origins of deep-sea communities at global scales. This is especially true for deep-sea invertebrates, including Amphipoda (Barnard, 1961; Thurston, 1990).

Although recent morphological and molecular studies have shed new light on the distribution and habitat niches of certain bentho-pelagic amphipods (e.g. Eurythenes) (Havermans, 2016; Narahara-Nakano et al., 2017), there is little published so far on how widespread other amphipod species may be. This lack of information on species richness and ecological uniqueness hampers the answering of crucial questions on recoverability from anthropogenic impacts. Ultimately this impedes ecologists from providing advice about sustainable deep-sea mining practices, thus underpinning the need for this dedicated deep-sea ecosystem research.

Here, we present distribution patterns of scavenging deepsea amphipod communities, with the first comparisons of their biogeography and community structures in two oceanic basins. These two basins are the research areas for simulating and studying the anthropogenic impacts of deep-sea nodule mining.

We are investigating whether there are differences and similarities in the species compositions of the two basins (e.g. richness, abundances) and further exploit a disturbance experiment to compare the biodiversity of this mining impact proxy to the undisturbed reference areas. We discuss the possible implications of our findings, aiming to use them to formulate recommendations regarding the pending deepsea mining of manganese nodule activities in the NE Pacific ecosystem.

\section{Material and methods}

\subsection{Study area}

We investigated the amphipod communities of two oceanic basins (Fig. 1): (i) the Clarion-Clipperton fracture zone (CCZ, $6 \times 10^{2} \mathrm{~km}^{2}, 7000 \mathrm{~km}$ wide), an economically important manganese nodule field in the NE Pacific, comprising several different contractor licence areas (who to date, have exploration licences only), and nine designated Areas of Particular Ecological Interest (APEIs) as designated by the International Seabed Authority (ISA) (Lodge et al., 2014), and (ii) the DISturbance and re-COLonisation (DisCOL) experimental area (DEA, $11 \mathrm{~km}^{2}, 4 \mathrm{~km}$ wide), a mining disturbance proxy (also containing manganese nodules) in the Peru Basin in the SE Pacific. In 1989, the DEA sediment bed was artificially disturbed using a plough harrow to create 78 track marks (Appendix A, Sect. A1) (Thiel, 1992). These are supposed to simulate the type of disruption that would be caused by a commercial mining operation. This baseline study was a new approach in deep-sea risk assessment and is still ongoing today, providing us with crucial data from this long-term ecological experiment.

\subsection{Sampling}

In 2015 (26 years after the first impact in the DEA in 1989), two research expeditions with the RV Sonne visited the CCZ (cruise SO239) and revisited the DEA (cruise SO242-1 and SO242-2) to assess if and how the deep-sea faunal communities had recovered within the DEA and to attempt to quantify their recolonization potential.

Amphipod samples were taken from the $\mathrm{CCZ}$ and DEA using a free-fall lander $(120 \mathrm{~cm} \times 120 \mathrm{~cm} \times 120 \mathrm{~cm})$, to which four plastic traps were attached (two $20 \mathrm{~cm} \times 25 \mathrm{~cm} \times 40 \mathrm{~cm}$ traps with $4 \mathrm{~cm}$ openings and two $25 \mathrm{~cm} \times 40 \mathrm{~cm} \times 60 \mathrm{~cm}$ traps with $8 \mathrm{~cm}$ openings), baited for each station with an $800 \mathrm{~g}$ mixture of mackerel, squid and shrimp. Using this specially designed deep-sea sampling equipment, more than 60000 specimens of scavenging amphipods were collected from the CCZ and the DEA sites.

The baited trap was deployed eight times across the CCZ at a depth range of 4116-4932 m (samples C1-C8) and five 


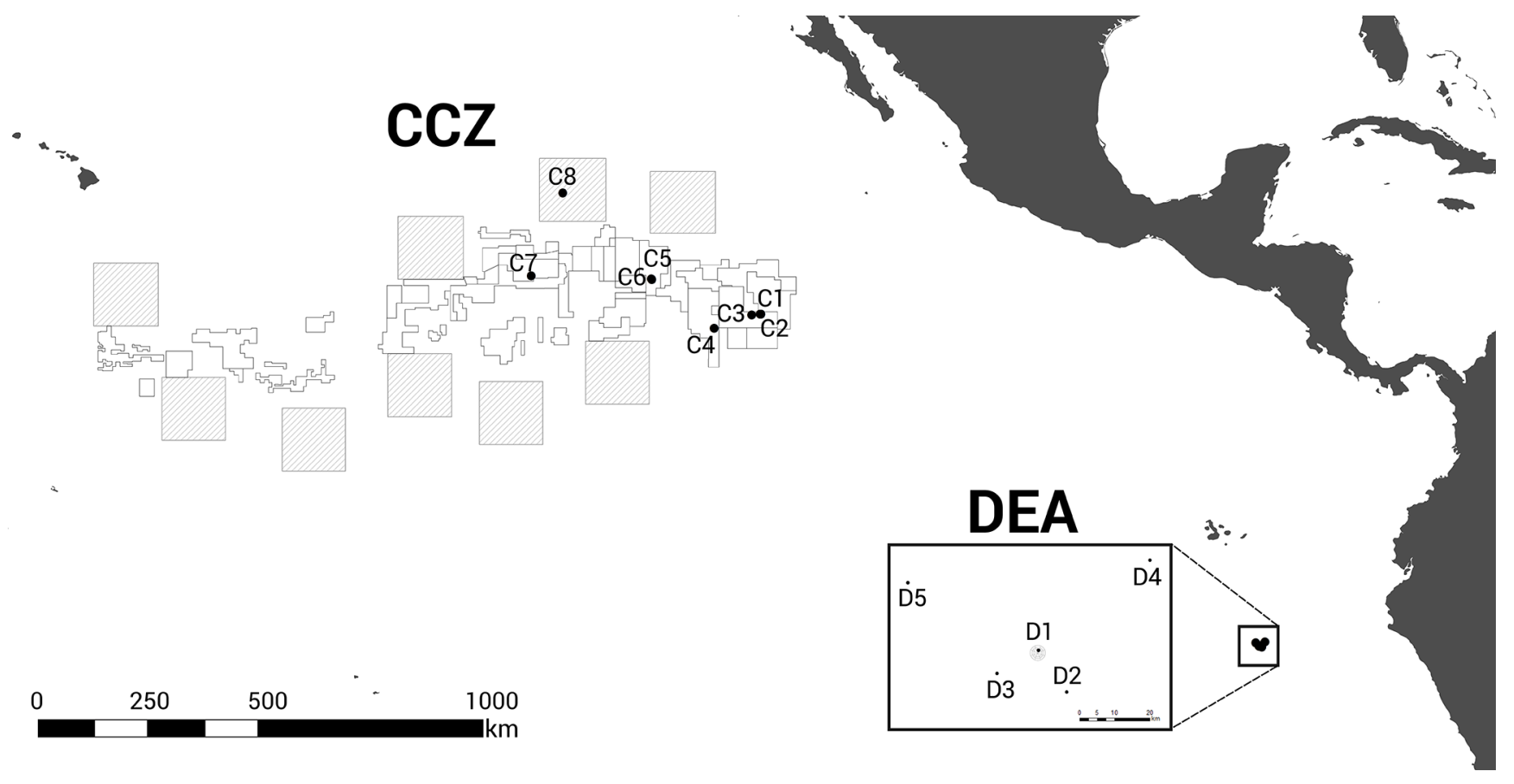

Figure 1. Geographic locations of the two study areas, the Clarion-Clipperton fracture zone (CCZ) (Northeast Pacific) and the DISturbance and re-COLonisation (DisCOL) experimental area (DEA) (Peru Basin, Southeast Pacific). There are nine Areas of Particular Ecological Interest (APEIs) in the CCZ region, which are illustrated by $400 \times 400 \mathrm{~km}^{2}$ grey boxes. White boxes indicate the various contractor licence areas in the CCZ. We deployed eight amphipod traps across the CCZ, which is $16000 \mathrm{~km}^{2}$ and $7000 \mathrm{~km}$ wide, and five in the DEA, which encompasses $11 \mathrm{~km}^{2}$ with a width of $4 \mathrm{~km}$.

times in the DEA at a depth range of 4078-4307 m (samples D1-D5; Fig. 1, Table 1). In the CCZ, we sampled within four different contractor licence areas (Table 1) to obtain a pre-disturbance baseline and to then compare it with one of the nine protected APEIs around the CCZ. In contrast, in the DEA sampling was conducted once within the disturbed area (D1), twice $10 \mathrm{~km}$ away (D2, D3) and twice $40 \mathrm{~km}$ away (D4, D5) from D1 in four surrounding reference areas (see Fig. 1).

\subsection{Processing}

On recovery of the lander, all traps were disconnected and placed in pre-cooled $\left(4^{\circ} \mathrm{C}\right)$ buckets of filtered seawater. All specimens were washed on board in a dedicated coolclimate laboratory $\left(4^{\circ} \mathrm{C}\right)$, morphologically pre-sorted and fixed in molecular grade (95\%) ethanol, before being stored at $-20^{\circ} \mathrm{C}$.

Detailed sorting and identifications were performed using the morphological species concept (Futuyma, 1998) and the keys of Schulenberger and Barnard (1976) and Barnard and Karaman (1991) to separate the samples into taxonomic "morphotypes". The larger fraction (> $15 \mathrm{~mm}$ length) has been identified to the lowest possible taxonomic resolution. Species not assigned with certainty are denoted here by as affiliated species (e.g. genus aff. species) or conferred species (e.g. genus cf. species).
Of the 60000 specimens, those with a size of less than $15 \mathrm{~mm}$ in length were excluded from the analysis because these were mostly juveniles and their morphological differences were not sufficiently pronounced to allow an accurate identification to the species or even genus level. Some pelagic amphipods were collected accidentally and omitted. Finally, genera containing multiple (and as yet) unidentified species have been summarized as "spp.".

\subsection{Statistical analyses}

Our null hypothesis $\left(H_{0}\right)$ here is that there are no differences in the amphipod biodiversity of the two basins. To test this hypothesis, we firstly calculated the alpha biodiversity of the two basins using the Simpson index $(D)$ (Simpson, 1949) (Sect. A4). Rarefaction was run on the longer than $15 \mathrm{~mm}$ fraction using default parameters. Individual-based curves were generated using the rarefy function of the "vegan" package in R 2.3.0 (Gotelli and Colwell, 2001; R Core Team, 2013) to compare species richness across all 13 sampling stations and to test for the completeness of sampling.

Secondly, to compare the beta biodiversity, we estimated the variability of the community compositions between sites. The Bray-Curtis dissimilarity metric (Bray and Curtis, 1957) was used to calculate differences between community compositions based on species densities, and the results were 
Table 1. Column 1 provides the new the station codes used in this paper in Figs. 1, 3, 4, and 6 and Table 3. The original station codes from cruises SO239 and SO242-1 are in column 2. Depth refers to the trap depth at the time of deployment.

\begin{tabular}{|c|c|c|c|c|c|c|c|c|}
\hline $\begin{array}{l}\text { Station } \\
\text { code }\end{array}$ & $\begin{array}{l}\text { Original } \\
\text { station } \\
\text { code }\end{array}$ & $\begin{array}{r}\text { Depth } \\
(\mathrm{m})\end{array}$ & $\begin{array}{l}\text { Known geological } \\
\text { features }\end{array}$ & Sampling area & $\begin{array}{r}\text { Residence } \\
\text { time } \\
(\mathrm{h}: \mathrm{m}: \mathrm{s})\end{array}$ & Lat & Long & $\begin{array}{l}\text { Nodule } \\
\text { presence }\end{array}$ \\
\hline $\mathrm{C} 1$ & SO239-33 & 4122 & Plains & German licence area & 100:20:00 & $11^{\circ} 51^{\prime} 17^{\prime \prime} \mathrm{N}$ & $117^{\circ} 03^{\prime} 23^{\prime \prime} \mathrm{W}$ & Yes \\
\hline $\mathrm{C} 2$ & SO239-37 & 4116 & Plains & German licence area & 125:49:00 & $11^{\circ} 48^{\prime} 56^{\prime \prime} \mathrm{N}$ & $117^{\circ} 00^{\prime} 58^{\prime \prime} \mathrm{W}$ & Yes \\
\hline $\mathrm{C} 3$ & SO239-63 & 4354 & Plains & German licence area & 66:07:00 & $11^{\circ} 48^{\prime} 32^{\prime \prime} \mathrm{N}$ & $117^{\circ} 32^{\prime} 13^{\prime \prime} \mathrm{W}$ & Yes \\
\hline $\mathrm{C} 4$ & SO239-96 & 4388 & Seamount & $\begin{array}{l}\text { Inter Ocean Metals } \\
\text { (IOM) licence area }\end{array}$ & 63:02:00 & $11^{\circ} 03^{\prime} 01^{\prime \prime} \mathrm{N}$ & $119^{\circ} 41^{\prime} 04^{\prime \prime} \mathrm{W}$ & Yes \\
\hline $\mathrm{C} 5$ & SO239-123 & 4529 & Plains & Belgian licence area & $26: 12: 00$ & $13^{\circ} 51^{\prime} 19^{\prime \prime} \mathrm{N}$ & $123^{\circ} 16^{\prime} 22^{\prime \prime} \mathrm{W}$ & Yes \\
\hline C6 & SO239-139 & 4516 & $\begin{array}{l}\text { Plains } \\
\text { north/south }+ \\
\text { seamount to west }\end{array}$ & Belgian licence area & $56: 33: 00$ & $13^{\circ} 50^{\prime} 31^{\prime \prime} \mathrm{N}$ & $123^{\circ} 14^{\prime} 59^{\prime \prime} \mathrm{W}$ & Yes \\
\hline $\mathrm{C} 7$ & SO239-173 & 4934 & Plains & French licence area & 79:40:00 & $14^{\circ} 02^{\prime} 45^{\prime \prime} \mathrm{N}$ & $130^{\circ} 07^{\prime} 56^{\prime \prime} \mathrm{W}$ & Yes \\
\hline $\mathrm{C} 8$ & SO239-205 & 4855 & Plains & $\begin{array}{l}\text { Area of Particular } \\
\text { Ecological Interest } \\
\text { (APEI 3) }\end{array}$ & $55: 59: 00$ & $18^{\circ} 46^{\prime} 53^{\prime \prime} \mathrm{N}$ & $128^{\circ} 19^{\prime} 59^{\prime \prime} \mathrm{W}$ & No \\
\hline D1 & SO242/1-8 & 4146 & Plains & Disturbed & $44: 26: 33$ & $07^{\circ} 04^{\prime} 66^{\prime \prime} \mathrm{S}$ & $88^{\circ} 27^{\prime} 49^{\prime \prime} \mathrm{W}$ & $\begin{array}{l}\text { Yes } \\
\text { (disturbed) }\end{array}$ \\
\hline D2 & $\mathrm{SO} 242 / 1-30$ & 4307 & Plains & South of disturbed & $51: 11: 18$ & $07^{\circ} 09^{\prime} 59^{\prime \prime} \mathrm{S}$ & $88^{\circ} 23^{\prime} 75^{\prime \prime} \mathrm{W}$ & Not known \\
\hline D3 & $\mathrm{SO} 242 / 1-55$ & 4043 & Seamount & Undisturbed reference & 25:09:09 & $07^{\circ} 07^{\prime} 13^{\prime \prime} \mathrm{S}$ & $88^{\circ} 32^{\prime} 98^{\prime \prime} \mathrm{W}$ & No \\
\hline D4 & SO242/1-68 & 4078 & Seamount & Undisturbed reference & $65: 20: 46$ & $06^{\circ} 52^{\prime} 13^{\prime \prime} \mathrm{S}$ & $88^{\circ} 12^{\prime} 72^{\prime \prime} \mathrm{W}$ & No \\
\hline D5 & $\mathrm{SO} 242 / 1-106$ & 4269 & Plains & Undisturbed reference & $47: 00: 50$ & $06^{\circ} 55^{\prime} 11^{\prime \prime} \mathrm{S}$ & $88^{\circ} 44^{\prime} 78^{\prime \prime} \mathrm{W}$ & Not known \\
\hline
\end{tabular}

then visualized in 2-D using a non-metric dimensional scaling (NMDS) plot. The ANOSIM function in the vegan package of R (R Core Team, 2013; Taguchi and Oono, 2005) was used to test the statistical significance of the differences in species compositions between the two study areas.

\section{Results}

\subsection{Basin biodiversity}

In total, 6916 scavenging amphipods $(>15 \mathrm{~mm}$ ) were collected from the 13 trap deployments in the two study areas, representing a total of 17 morphotypes (Fig. 2). In the CCZ, we collected 3932 individuals, which represent 10 morphotypes. Five of these have been identified to the species level: Abyssorchomene distinctus (Birstein and Vinogradov, 1960), Abyssorchomene gerulicorbis (Schulenberger and Barnard, 1976), Eurythenes sigmiferus (d'Udekem d'Acoz and Havermans, 2015), Paralicella caperesca (Schulenberger and Barnard, 1976) and Paralicella tenuipes Chevreux, 1908. Two are affiliated to a species (Paracallisoma aff. alberti and Valettietta cf. gracilis) and the remaining three are at least affiliated to a genus (Table 2). The 2984 individuals from the DEA represent 15 morphotypes. Six of these have been identified to the species level: Abyssorchomene distinctus (Birstein and Vinogradov, 1960), Abyssorchomene gerulicorbis (Schulenberger and Barnard, 1976), Eurythenes sigmiferus (d'Udekem d'Acoz and Havermans, 2015), Paralicella caperesca (Schulenberger and Barnard, 1976), Parandaniexis mirabilis Schellenberg, 1929, and Tectovalopsis regelatus Barnard and Ingram, 1990. A further five which have been affiliated with a species include Eurythenes aff. gryllus, Eurythenes aff. magellanicus, Paracallisoma aff. alberti, Stephonyx sp. nov. aff. arabiensis and Valettietta cf. gracilis. The remaining four have been identified to at least an affiliated genus (Table 2).

There are eight morphotypes shared between the basins: Abyssorchomene distinctus (Birstein and Vinogradov, 1960), Abyssorchomene gerulicorbis (Schulenberger and Barnard, 1976), Abyssorchomene spp., Eurythenes sigmiferus (d'Udekem d'Acoz and Havermans, 2015), Eurythenes spp., Paracallisoma aff. alberti, Paralicella caperesca (Schulenberger and Barnard, 1976) and Valettietta cf. gracilis (Fig. 2).

Two morphotypes were found only in the CCZ (Hirondellea sp. and Paralicella tenuipes Chevreux, 1908, and seven morphotypes were found only in the DEA (Eurythenes aff. gryllus, Eurythenes aff. magellanicus, gen. aff. Cleonardo, 
Table 2. Distribution and abundances of morphotypes across the Clarion-Clipperton fracture zone (CCZ) and DisCOL experimental area (DEA). For the numerical values the following format has been used: normal font is shared, italic font is DEA only and bold font is CCZ only.

\begin{tabular}{|c|c|c|c|c|c|c|c|c|c|c|c|c|c|}
\hline Taxa & $\mathrm{C} 1$ & $\mathrm{C} 2$ & $\mathrm{C} 3$ & $\mathrm{C} 4$ & $\mathrm{C} 5$ & C6 & $\mathrm{C} 7$ & $\mathrm{C} 8$ & D1 & D2 & D3 & D4 & D5 \\
\hline Abyssorchomene distinctus & 629 & 312 & 180 & 170 & 64 & 47 & 2 & 25 & 9 & 3 & 25 & 0 & 5 \\
\hline Abyssorchomene gerulicorbis & 73 & 47 & 48 & 107 & 71 & 65 & 184 & 121 & 351 & 143 & 522 & 178 & 595 \\
\hline Abyssorchomene spp. & 0 & 0 & 50 & 0 & 0 & 3 & 0 & 0 & 5 & 20 & 0 & 0 & 0 \\
\hline Eurythenes aff. gryllus & & & & & & & & & 119 & 0 & 9 & 0 & 9 \\
\hline Eurythenes aff. magellanicus & & & & & & & & & 0 & 0 & 59 & 0 & 47 \\
\hline Eurythenes sigmiferus & 9 & 3 & 35 & 11 & 12 & 5 & 0 & 6 & 30 & 61 & 127 & 36 & 22 \\
\hline Eurythenes spp. & 6 & 3 & 2 & 0 & 0 & 20 & 1 & 12 & 0 & 91 & 3 & 39 & 1 \\
\hline gen. aff. Cleonardo & & & & & & & & & 1 & 0 & 0 & 0 & 0 \\
\hline Hirondellea sp. & $\mathbf{0}$ & 2 & $\mathbf{0}$ & $\mathbf{0}$ & $\mathbf{0}$ & $\mathbf{0}$ & 5 & 10 & & & & & \\
\hline Paracallisoma aff. alberti & 0 & 0 & 0 & 0 & 0 & 2 & 1 & 6 & 10 & 4 & 0 & 1 & 1 \\
\hline Paralicella caperesca & 104 & 4 & 114 & 152 & 255 & 75 & 63 & 460 & 86 & 108 & 80 & 21 & 7 \\
\hline Paralicella tenuipes & 22 & $\mathbf{0}$ & 14 & 42 & 43 & 9 & 19 & 58 & & & & & \\
\hline Parandania sp. & & & & & & & & & 5 & 2 & 42 & 5 & 1 \\
\hline Parandaniexis mirabilis & & & & & & & & & 11 & 0 & 3 & 0 & 0 \\
\hline Stephonyx sp. nov. aff. arabiensis & & & & & & & & & 0 & 4 & 0 & 0 & 0 \\
\hline Tectovalopsis regelatus & & & & & & & & & 5 & 0 & 0 & 0 & 0 \\
\hline Valettietta cf. gracilis & 75 & 11 & 29 & 3 & 2 & 5 & 1 & 23 & 2 & 29 & 17 & 1 & 29 \\
\hline
\end{tabular}

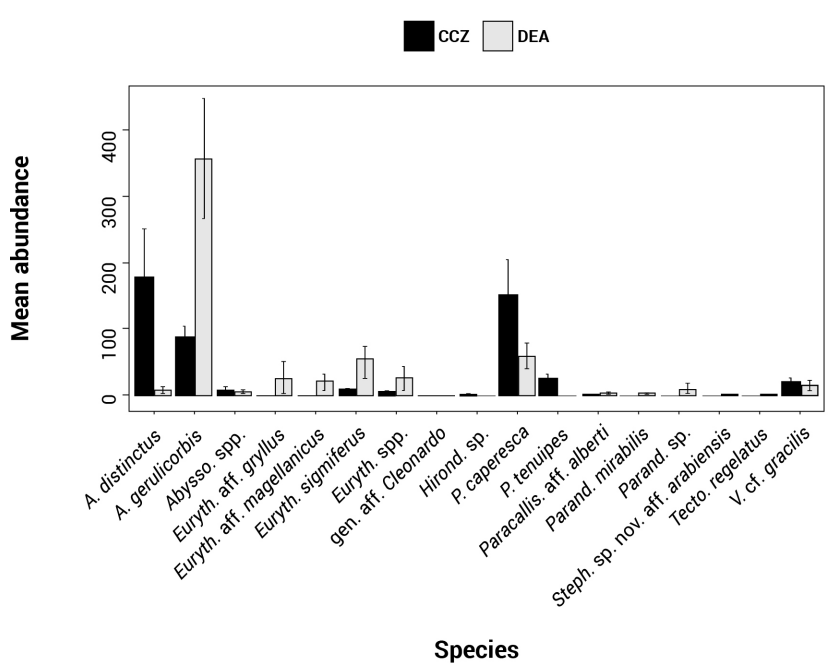

Figure 2. Histogram showing the species assemblage for the scavenging community in the Clarion-Clipperton fracture zone (CCZ) (black) and the DisCOL experimental area (DEA) (grey). The abundances of 17 morphotypes are shown.

Parandania sp., Parandaniexis mirabilis Schellenberg, 1929, Stephonyx sp. nov. aff. arabiensis, and Tectovalopsis regelatus Barnard and Ingram, 1990 (Table 2).

\subsection{Sampling completeness}

Due to differences in allocated ship times (the CCZ cruise being $52 \mathrm{~d}$ and the DEA cruise being $29 \mathrm{~d}$ ), the trap deployments were not identical, making it necessary to check the effect of the different deployment times. The resulting catch-

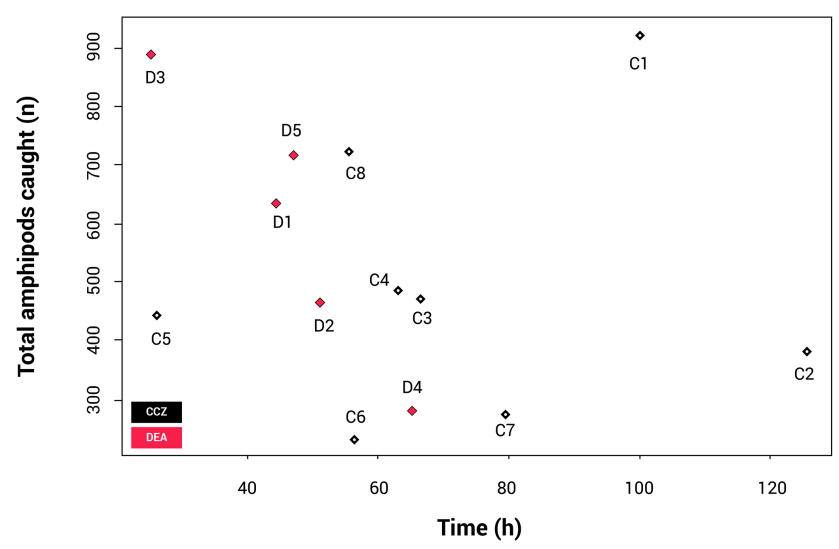

Figure 3. Catch per unit effort (CPUE), illustrating the correlation between sampling time and number of individuals collected. Only the longer than $15 \mathrm{~mm}$ fraction was included here.

per-unit-effort (CPUE) plot (Fig. 3) shows that there is no statistically significant correlation between the length of time the trap was at the seafloor and total number of amphipods caught $(p=0.551)$.

The rarefaction results (Fig. 4) show that the curves for nine stations reach a plateau, indicating that sampling effort was sufficient to assess diversity levels. These include all CCZ stations except C7. In contrast, four of the five curves for the DEA (stations D1, D2, D4 and D5) are unsaturated. A higher number of different species were collected at D1 and D2; however, many of these were singletons or doubletons, with A. gerulicorbis dominating at both the disturbed station and the station closest to the disturbed area (D2). 


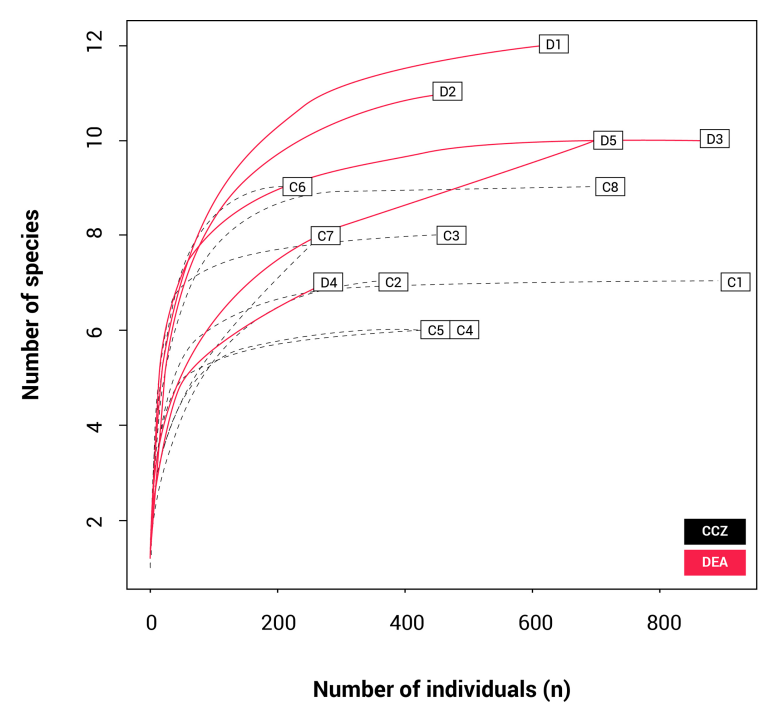

Figure 4. Species rarefaction curves for each of the 13 trap stations across both areas, the Clarion-Clipperton fracture zone and the DisCOL experimental area. Only individuals longer than $15 \mathrm{~mm}$ were considered here.

\subsection{Biodiversity}

Figure $5 \mathrm{a}$ and $\mathrm{b}$ show that the scavenging community in the CCZ is dominated by three species, A. distinctus (Birstein and Vinogradov, 1960) (36\%), A. gerulicorbis (Schulenberger and Barnard, 1976) (18\%) and Paralicella caperesca (Schulenberger and Barnard, 1976) (31\%), whereas, in contrast, the DEA scavenging community is dominated by a single species, A. gerulicorbis (Schulenberger and Barnard, 1976), accounting for almost $60 \%$ of all specimens. The Simpson index $(D)$ for the entire CCZ area is (with 0.73) higher than the 0.62 that was calculated for the whole of the DEA area (Table 3). The biodiversity of each individual station was further explored (Table 3). In the CCZ, the lowest biodiversity was found at C3 and C6 $(D=0.23)$ and the highest at $\mathrm{C} 2(D=0.67)$. In the DEA, the lowest biodiversity of $D=0.36$ was found at station D1 (the site of the actual disturbance) and just south of the disturbance site at D2 (0.21), while the highest biodiversity was observed at D5 $(D=0.61)$ (Table 3).

\subsection{Species composition}

The NMDS shows that the communities of the two basins are dissimilar (ANOSIM: $p=0.002$ ); Fig. 6). The disturbed area in the DEA (D1) shows a clear difference from the four reference areas (D2-5). When the communities between the two basins are compared, D2 appears to be most similar to the $\mathrm{CCZ}$ community, and more specifically similar to $\mathrm{C} 6, \mathrm{C} 7$ and $\mathrm{C} 8$. The reliability of the data ranking is supported by a low stress value of 0.01 .
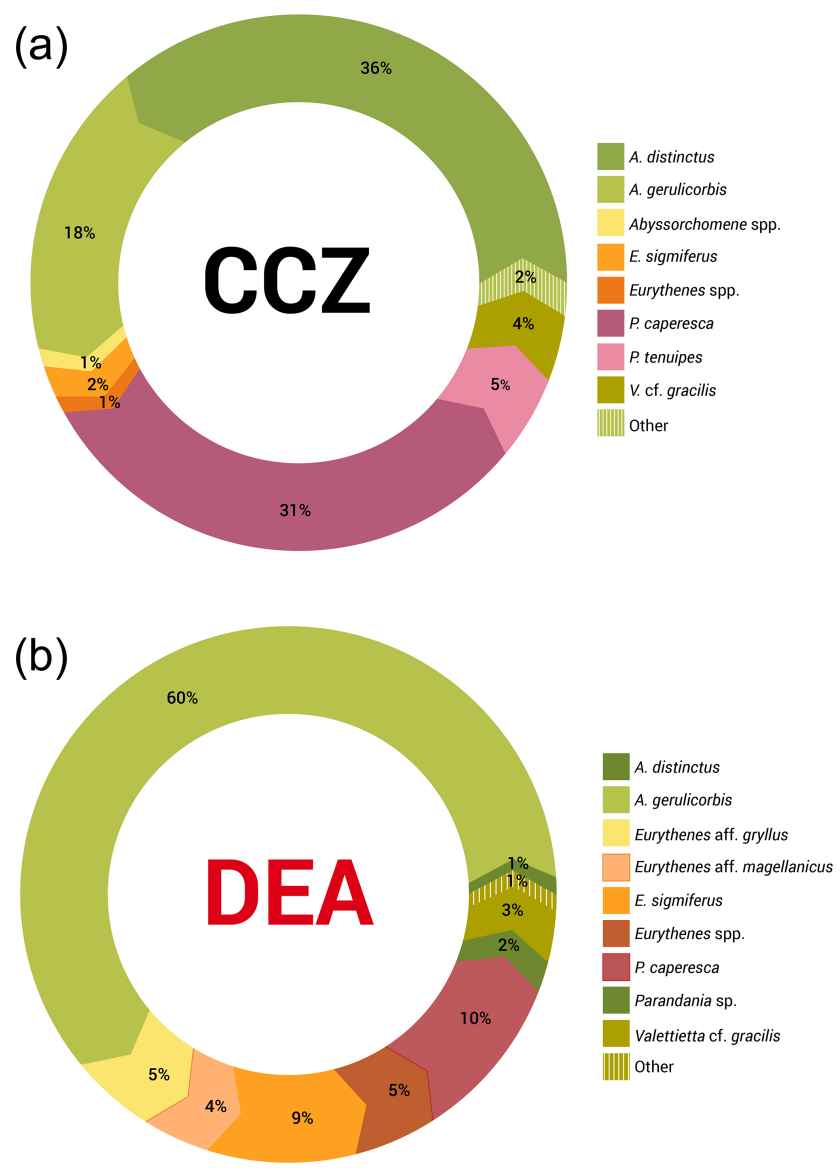

Figure 5. Relative species abundances in the Clarion-Clipperton fracture zone and the DisCOL experimental area. These abundances represent the longer than $15 \mathrm{~mm}$ subsample of the scavenging amphipod community.

Table 3. Comparison of biodiversity calculated using the Simpson index $(D)$ for the Clarion-Clipperton fracture zone and DisCOL experimental area and $D$ for each station is shown for further comparisons within these areas.

\begin{tabular}{|c|c|}
\hline Site & Simpson index $(D)$ \\
\hline Clarion-Clipperton fracture zone & 0.73 \\
\hline DisCOL experimental area & 0.62 \\
\hline $\mathrm{C} 1$ & 0.41 \\
\hline $\mathrm{C} 2$ & 0.68 \\
\hline $\mathrm{C} 3$ & 0.23 \\
\hline $\mathrm{C} 4$ & 0.27 \\
\hline $\mathrm{C} 5$ & 0.38 \\
\hline $\mathrm{C} 6$ & 0.23 \\
\hline $\mathrm{C} 7$ & 0.45 \\
\hline C8 (APEI) & 0.44 \\
\hline D1 (disturbed) & 0.36 \\
\hline D2 (ref 1, close to disturbed) & 0.21 \\
\hline D3 ref 2 & 0.38 \\
\hline D4 ref 3 & 0.44 \\
\hline D5 ref 4 & 0.61 \\
\hline
\end{tabular}




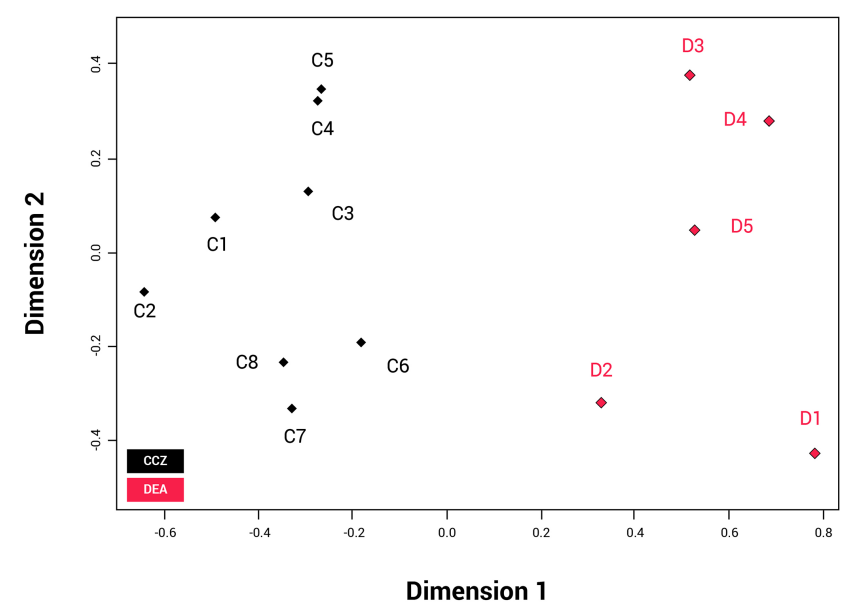

Figure 6. NMDS plot showing the beta biodiversity (dissimilarities or similarities) for each of the 13 amphipod trap sampling stations associated with the two basins, Clarion-Clipperton fracture zone (CCZ) (black) and the DisCOL experimental area (DEA) (red). Data are supported by a low stress value of 0.01 .

\section{Discussion}

\subsection{An unexplored ecosystem}

Although the most recent and comprehensive analysis of the animal diversity of the world's oceans estimates a total of less than a million species over all depths (Appeltans et al., 2012), it is not currently known how many species inhabit the deep sea. Over 7000 marine amphipod species have been found below $2000 \mathrm{~m}$. These numbers are reduced to 173 known species, 87 genera and 37 families at depths below $3000 \mathrm{~m}$, and 100 known species, 66 genera and 31 families are known to occur below $4000 \mathrm{~m}$ (Vader, 2005; Brandt et al., 2012).

\subsection{Lysianassoidea and their biogeography}

The superfamily Lysianassoidea constitutes an important part of the abyssal amphipod fauna. Also, in our sampling, lysianassoid amphipods were collected in large numbers ( $99 \%$ of the samples taken in both basins). As a superfamily, they comprise $23 \%$ of all the species found below $2000 \mathrm{~m}$, $35 \%$ of the species found below $3000 \mathrm{~m}$ and $31 \%$ of the species found below $4000 \mathrm{~m}$ (Brandt et al., 2012).

Many species in the Lysianassoidea occur in multiple abyssal basins and some even have worldwide distributions (Thurston, 1990). Despite the Ocean Biogeographic Information System (OBIS) database containing 615650 records of Amphipoda, many of these are shelf or pelagic species, with very few records from the CCZ and DEA (OBIS, 2019). Here, we provide additional data for the known bathymetric range of the seven amphipods, which we have identified to species level: Abyssorchomene distinctus (Birstein and Vinogradov, 1960), Abyssorchomene gerulicorbis (Schulenberger and Barnard, 1976), Eurythenes sigmiferus (d'Udekem d'Acoz and Havermans, 2015), Paralicella caperesca (Schulenberger and Barnard, 1976), Paralicella tenuipes Chevreux, 1908, Parandaniexis mirabilis Schellenberg, 1929, and Tectovalopsis regelatus Barnard and Ingram, 1990 (Table 2). In addition, we have found two possibly new species of Eurythenes, previously not known from these basins, which we plan to analyse further in the future.

While we only sampled Hirondellea sp. and Paralicella tenuipes Chevreux, 1908, in the CCZ, Eurythenes aff. gryllus, Eurythenes aff. magellanicus, gen. aff. Cleonardo, Parandania sp., Parandaniexis mirabilis Schellenberg, 1929, Stephonyx sp. nov. aff. arabiensis, and Tectovalopsis regelatus Barnard and Ingram, 1990, only in the DEA, we cannot conclude based on the current data only if these species are unique to their respective basins without confirming these distribution patterns with additional sampling campaigns.

Despite the sampling campaign in the $\mathrm{CCZ}$ being twice as long as the DEA, the number of individuals and species collected does not correlate positively with deployment effort. We posit that this is rather an effect of abiotic and organic factors, such as the productivity-driven gradients in the CCZ, which decrease from east to west and from north to south (Hannides and Smith, 2003), and also the productivity differences between both basins.

\subsection{Biodiversity within basins}

Figure 5a and $\mathrm{b}$ clearly show that the DEA scavenging community has reduced abundances of all species, including $A$. distinctus (Birstein and Vinogradov, 1960) (1\%) and $P$. caperesca (Schulenberger and Barnard, 1976) (7\%), and is now dominated by a single species, A. gerulicorbis (Schulenberger and Barnard, 1976), accounting for $60 \%$ of the DEA community. This indicates an interesting resilience and flexibility in the latter species. Similar patterns have been observed in Potter Cove (Seefeldt et al., 2018), where, following glacial retreat, a change in sedimentation rates led to the dominance of a single scavenging amphipod species, Cheirimedon femoratus (Pfeffer, 1888).

The assemblages of the two basins have some overlap in their biodiversity (as is exemplified by the eight shared morphotypes). However, the sampling stations and the two basins as a whole are heterogeneous in their species compositions.

Thus, we can observe some negative influence (possibly attributed to the disturbance in the DEA) on the scavenging amphipod community. This reduced biodiversity is reflected in the higher Simpson index $(D)$ for the CCZ $(0.73)$ as compared to the DEA $(D=0.62$; Table 3$)$.

To explore whether this reduced diversity in the DEA was truly an artefact of the simulated disturbance, $D$ was also calculated for each sampling station within each basin (Table 3).

In the CCZ, the APEI (C8) shows a moderate level of biodiversity $(D=0.44)$, indicating that it is not optimally placed for representing the biodiversity of the scavenging amphipod community of the CCZ. Additionally, this pre-existing lower 
biodiversity (in comparison to the contractor licence areas), indicates that the APEI may not serve well as a refugium for amphipods post-disturbance. However, due to the fact that only one of the nine APEIs has been investigated thus far, this APEI along with the remaining eight would need to be sampled.

Within the DEA, the lowest biodiversities are calculated at the site of the disturbance (D1) and south of it (D2; Table 3), indicating that the reduced biodiversity in the DEA could indeed be caused by the simulated disturbance in 1989 (Thiel, 1992).

The highest abundances in the DEA were collected from station D5 $(n=717)$; this station also has the highest Simpson index within the DEA $(D=0.61)$ (Table 3). Bathymetric imaging shows a seamount range to the northwest (NW) of the disturbed area (D1) (Sect. A3). Although the relief change is only $150 \mathrm{~m}$, the range extends laterally for several kilometres, hampering dispersal across barriers such as sills, canyons and ridges (Smith et al., 2006; Blankenship et al., 2006; Etter et al., 2011). However, recent studies have shown that due to their mobile nature, geographic isolation alone would not pose a true barrier to bentho-pelagic amphipod species (Havermans, 2016; Ritchie et al., 2016) and thus cannot explain why such a high number of large scavenging individuals was collected at station D5.

\subsection{Community similarities}

Scavenging amphipods are resilient and dispersive, but most importantly they are highly mobile (Ingram and Hessler, 1983; Lörz et al., 2018). Often driven by their search for erratically deposited feeding opportunities (Smith et al., 1989), they are probably less constrained by local environmental abiotic conditions and seafloor topography.

Beta diversity can be regarded as the dissimilarities in species composition between spatially different communities. As an indication for beta biodiversity, the NMDS (Fig. 6) shows a significant separation in the similarity index between the two basins (ANOSIM $p=0.002$ ). However, despite the dispersive and resilient nature of scavenging amphipods, their biodiversity could have been affected by the disturbance experiment, as evidenced by the NMDS (Fig. 6), where the disturbed area (D1) and the area closest to it (D2) show a different Bray-Curtis index to the remaining three reference sites (D3, D4 and D5).

In the CCZ, stations $\mathrm{C} 1, \mathrm{C} 2, \mathrm{C} 3, \mathrm{C} 4$ and $\mathrm{C} 5$ show a different Bray-Curtis index in comparison to stations $\mathrm{C} 6, \mathrm{C} 7$ and $\mathrm{C} 8$ (Fig. 6). The $\mathrm{CCZ}$ is a geomorphologically very heterogeneous region, with seamounts of $200 \mathrm{~m}$ altitude running from north to south. A barrier of this height would be expected to affect sedimentation rates, nodule presence and currents. Furthermore, the difference in depth from the eastern edge $(3950 \mathrm{~m})$ and the western edge $(5150 \mathrm{~m})$ is more than $1200 \mathrm{~m}$. These combined factors very likely give rise to different trends in species composition (Glover et al., 2016).
However, since it has been established that bentho-pelagic amphipods are less sensitive to such barriers (Havermans, 2016), at this stage other biotic (e.g. the productivity gradient) and abiotic factors causing this separation cannot be excluded as alternative explanations.

\subsection{Dispersal and connectivity}

Whilst the NMDS (Fig. 6) illustrates a visual separation of the two basins, there is also some similarity in the amphipod fauna between the two areas (as is obvious by the eight shared species), indicating that the dispersal extent for these eight species might be up to at least $3000 \mathrm{~km}$. However, this hypothesis will need to be confirmed with subsequent molecular analyses.

Abyssal amphipods have been shown to be able to travel actively at speeds of almost $4 \mathrm{~cm} \mathrm{~s}^{-1}$ (Laver et al., 1985), even at temperatures as low as $3^{\circ} \mathrm{C}$ (Kankaanpää et al., 1995). It is obvious that they are sufficiently strong to swim up weak currents since they can be found several hundred metres above the seafloor searching pelagically for mates (e.g. Eurythenes gryllus occurring up to $1800 \mathrm{~m}$ above the seafloor) (Thurston, 1990; Havermans et al., 2013) or following food falls (Baldwin and Smith Jr., 1987).

However, it is apparent that the dispersal of abyssal amphipods is not always contingent on current direction but on passive dispersal. Amphipods can also be carried passively over long distances by strong currents (e.g. the circumpolar current of the Southern Ocean) (Laver et al., 1985), but even weaker deep-sea currents have been suggested as a mechanism for deep-sea dispersal of amphipods (e.g. Eurythenes gryllus; Schüller and Ebbe, 2007). This, coupled with their ability to follow odour plumes (Ide et al., 2006; Premke et al., 2003), significantly increases the probability and extent of their dispersal (Conlan, 1991; Highsmith, 1985). Specialist feeding adaptations for several species found in our assemblages have been reported in Havermans and Smetacek (2018). For example, the semi-tubular flap-like molars of the genera Hirondellea and Eurythenes and the distendible foregut of Abyssorchomene and midgut of Paralicella. It is not clear from our study in the absence of particulate organic carbon (POC) data for the areas of the trap deployments whether the biogeography of these specialized feeders is linked to the productivity gradients in these two basins. The lack of a clear dispersal pattern is obvious from Fig. 6, where station $\mathrm{D} 2$ is the station plotted closest with the CCZ basin in terms of species composition despite station D5 being geographically the shortest distance away from the CCZ.

Recent research on Eurythenes gryllus has demonstrated that it thrives in every ocean with a wide (pelagic-hadal) depth range. However, assumptions that individual morphotypes of this species belong to the same genetic lineage have been challenged (Havermans et al., 2013; Havermans, 2016). Ritchie et al. (2016) demonstrated with microsatellite markers heterozygote deficiency in Paralicella tenuipes 
Chevreux, 1908, which they attributed to cryptic diversity. It is likely that some of the eight shared species between the two basins are cryptic species, which will be tested by ongoing molecular research.

Unfortunately, in the absence of data on deep-sea currents in the study area, especially between the CCZ and DEA, it is not yet possible to fully explain the drivers and mechanisms of amphipod dispersal between these particular basins.

\subsection{The DisCOL experimental area as a proxy}

Higher abundances of scavenging amphipods were collected from the CCZ (3932 individuals) as opposed to the DEA (2984 individuals). Yet, we have identified more morphotypes in the DEA (15) than in the CCZ (10), indicating that the DEA is more speciose and thus more biodiverse.

However, although the DEA is more speciose, many of its morphotypes were collected in low abundances, with several of these being singletons or doubletons (collected from one or two sampling stations only). This is reflected in the rarefaction curves (Fig. 4), which indicate thorough sampling in the $\mathrm{CCZ}$ with all but station $\mathrm{C} 7$ reaching asymptotes. In contrast, four stations in the DEA (D1, D2, D4 and D5) are unsaturated. This pattern suggests first that the less abundant species that are present at fewer stations may not necessarily be rare species and second that there could be as of yet undetected biodiversity in the DEA.

Our preliminary (basin-scale) comparison of the scavenging communities of the two study areas shows that even if the DEA is a small-scale disturbance experiment, it is a very diverse area. Thus, the DEA is a well-chosen site for monitoring the impacts of disturbance and instrumental in its role as a proxy to assess impending mining activities in the CCZ.

\subsection{Future research}

At several stations in both basins, we collected amphipods in very high abundances (C1, C8, D3 and D5) (Table 2). Since biotic production is contingent on the sinking flux of particles from the euphotic zone (Sweetman et al., 2017), the biodiversity differences at each of the 13 stations could be driven by POC or erratic whale falls (Smith et al., 1989). However, not all feeding behaviour of scavenging amphipods is based on opportunistic or erratic availability of nutrients (Havermans and Smetacek, 2018). During future sampling campaigns, the POC of these amphipod sampling areas should be monitored, along with experiments on different types of food fall in addition to obtaining side-scan sonar and abiotic data. This will provide a more comprehensive view of the food types required for these species to thrive in the deep sea.
It is not clear from our results whether substrate type (i.e. nodule or non-nodule) has any effect on the amphipod communities (Smith and Demopoulos, 2003) since these kinds of data are only available for stations D3 and D4. To answer this question, resampling of the study areas in combination with an ocean floor observation system (OFOBS) (video or camera) is required.

Although our study only addresses the scavenging amphipod species longer than $15 \mathrm{~mm}$, we have already found indications of a possible disturbance effect in the DEA. It is obvious that scavenging amphipods are only one of several bentho-pelagic impact-indicator groups. Other truly benthic groups such as sponges or less dispersive amphipods (e.g. collected by the EpiBenthic Sledge, EBS) may demonstrate an even more pronounced impact of mining activities and should be investigated in future studies.

With the application of molecular techniques to identify cryptic species (Delić et al., 2017), more realistic estimates of biodiversity can be obtained (Schön et al., 2012), improving our current knowledge of the biodiversity of this area. If these improved estimates of biodiversity also include cryptic species, it is possible that the biological impact of manganese nodule mining on amphipod and other deep-sea faunal communities may turn out to be even higher.

\section{Conclusions}

In summary, this study on the scavenging amphipod community of two abyssal oceanic basins has demonstrated that amphipods are present in high abundances across the CCZ and DEA, with eight shared species and some morphotypes possibly being unique to their respective basin.

Our results have indicated that the simulated mining experiment may have had an impact on the biodiversity of these scavenging amphipods, as demonstrated by the low alpha biodiversity of the DEA overall at the disturbance site itself (D1) and the $60 \%$ dominance of A. gerulicorbis (Schulenberger and Barnard, 1976) in this region.

Given the scarcity of sampling and industry experience of marine habitats at these depths, the formulation of effective regulations is challenging (International Seabed Authority, 2017). Nonetheless, our study provides the first results on possible effects of disturbance activities on the abyssal amphipod biodiversity of deep-sea basins. 


\section{Appendix A}

A1 Bathymetric map (Peru Basin, disturbance proxy) showing the simulated seafloor mining impact discussed in this paper

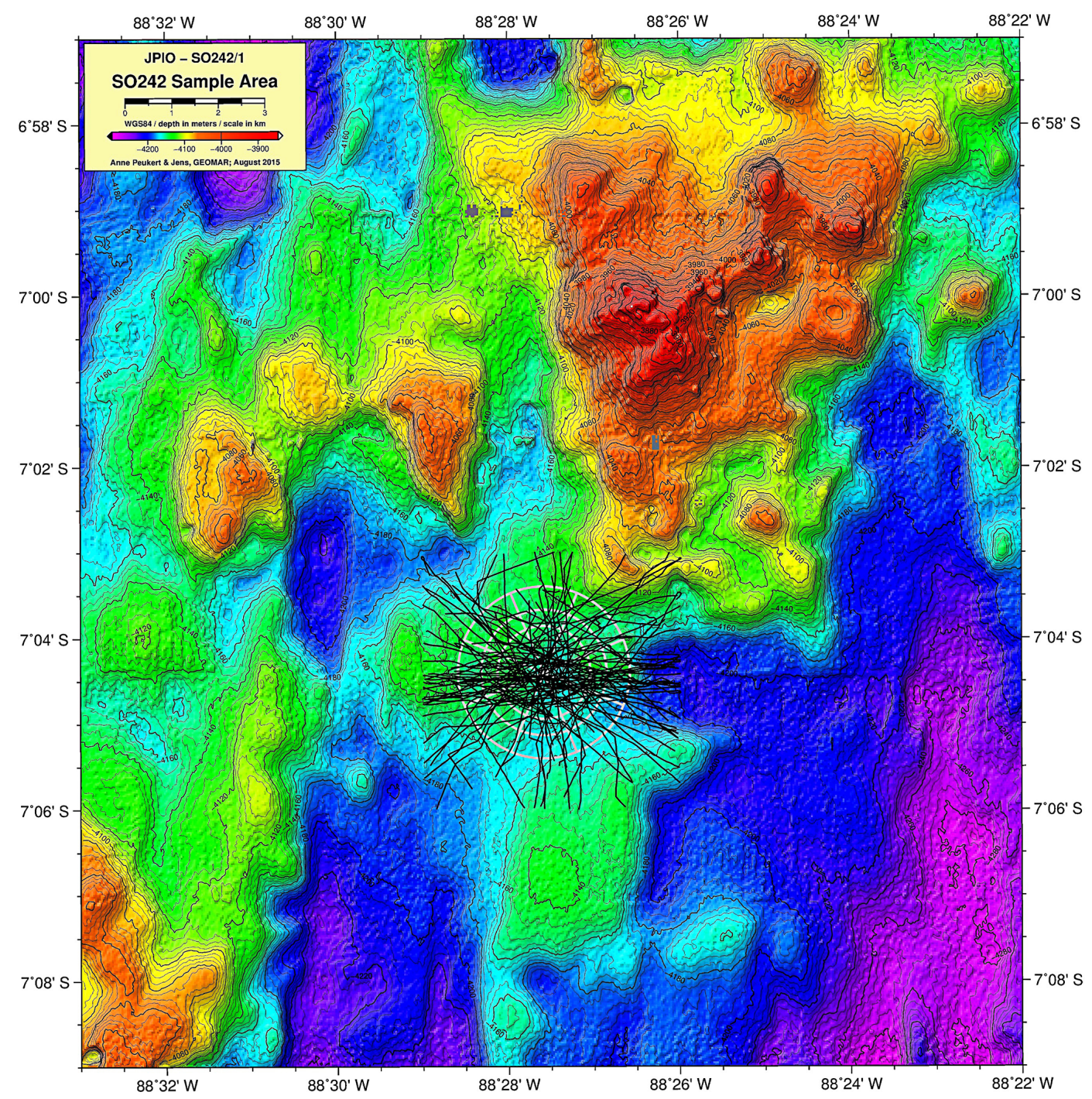

Figure A1. Multibeam scan showing the location of the 78 track marks created by the plough harrow in the DisCOL experimental area to simulate manganese nodule extraction activity (D1). 
A2 Visual information on the field gear deployed during expeditions SO239 and SO242/1

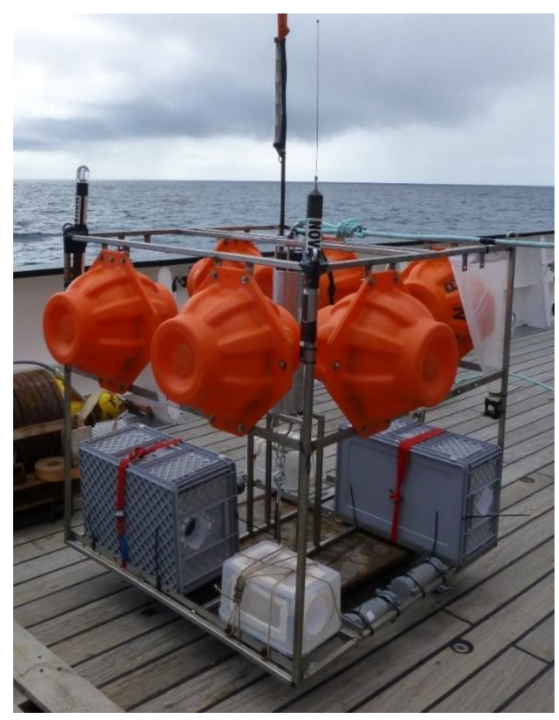

Figure A2. Photograph showing the baited free-fall lander trap designed and deployed by RBINS. Equipped with an acoustic release transponder, flashlight, Novotech radio beacon and Posidonia positioning signal to monitor position at the sea floor and ascension through the water column.

\section{A3 Bathymetric map (Peru Basin) visualizing relief changes in the context of dispersal barriers}

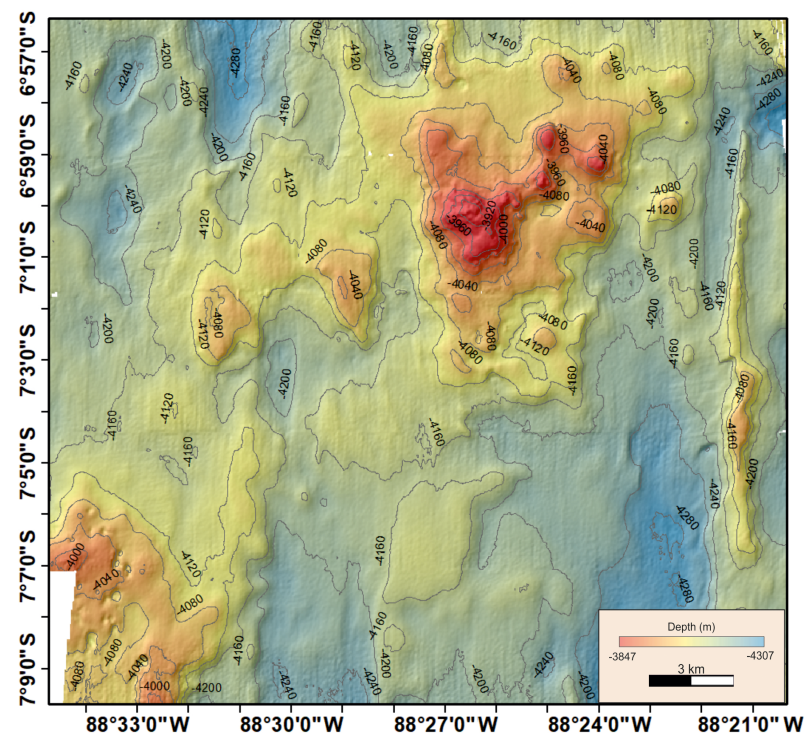

Figure A3. Relief changes in the DisCOL Experimental Area. (C) GEOMAR-Helmholtz-Centre for Ocean Research Kiel, Germany. Acknowledgement: Anne Henke.

\section{A4 Calculation of alpha biodiversity used in this paper}

Simpson index was used for the calculation of alpha biodiversity as follows.

Simpson Diversity Index $(D)=1-\frac{\sum n(n-1)}{N(N-1)}$

$D$ is the diversity index, $n$ is the number of individuals in each particular species and $N$ is the total number in the community. A high value of $D$ indicates a high species diversity. 
Data availability. The data discussed in the paper are available at https://doi.pangaea.de/10.1594/PANGAEA.914677 (Patel, 2020).

Sample availability. Biological samples pertaining to this paper are stored at the Royal Belgian Institute of Natural Sciences, Brussels, Belgium.

Author contributions. TP was responsible for the execution of fieldwork during expedition SO242/1, onboard and subsequent taxonomic work, data analysis, and writing of the manuscript. HR was responsible for the execution of fieldwork during expeditions SO239 and SO242/1 and onboard identifications of the amphipods. CD'UD'A was responsible for providing taxonomic expertise and the reading, editing and approval of the manuscript. KM, IDM, SD and IS were responsible for the design of this study and the reading, editing and approval of the manuscript.

Competing interests. The authors declare that they have no conflict of interest.

Special issue statement. This article is part of the special issue "Assessing environmental impacts of deep-sea mining - revisiting decade-old benthic disturbances in Pacific nodule areas". It is not associated with a conference.

Acknowledgements. The authors would like to acknowledge the Belgian Science and Policy Office (BELSPO) and the German Federal Ministry of Research and Education for their funding. We would also like to thank the crew of the Research Vessel "Sonne", the University of Ghent (Ghent, Belgium) and Tim Plevoets. This research paper would not have been possible without their support.

Financial support. This research has been supported by the JPI-Oceans project "Mining Impact" (BELSPO grant no. BR/15/MA/JPI-DEEPSEA2).

Review statement. This paper was edited by Ann Vanreusel and reviewed by Charlotte Havermans and Cene Fiser.

\section{References}

Appeltans, W., Ahyong, S. T., Anderson, G., Angel, M. V., Artois, T., Bailly, N., Bamber, R., Barber, A., Bartsch, I., Berta, A., Błażewicz-Paszkowycz, M., Bock, P., Boxshall, G., Boyko, C. B., Brandão, S. N., Bray, R. A., Bruce, N. L., Cairns, S. D., Chan, T. Y., Cheng, L., Collins, A. G., Cribb, T., Curini-Galletti, M., Dahdouh-Guebas, F., Davie, P. J., Dawson, M. N., De Clerck, O., Decock, W., De Grave, S., de Voogd, N. J., Domning, D. P., Emig, C. C., Erséus, C., Eschmeyer, W., Fauchald, K., Fautin, D. G., Feist, S. W., Fransen, C. H., Furuya, H., Garcia-Alvarez,
O., Gerken, S., Gibson, D., Gittenberger, A., Gofas, S., GómezDaglio, L., Gordon, D. P., Guiry, M. D., Hernandez, F., Hoeksema, B. W., Hopcroft, R. R., Jaume, D., Kirk, P., Koedam, N., Koenemann, S., Kolb, J. B., Kristensen, R. M., Kroh, A., Lambert, G., Lazarus, D. B., Lemaitre, R., Longshaw, M., Lowry, J., Macpherson, E., Madin, L. P., Mah, C., Mapstone, G., McLaughlin, P. A., Mees, J., Meland, K., Messing, C. G., Mills, C. E., Molodtsova, T. N., Mooi, R., Neuhaus, B., Ng, P. K., Nielsen, C., Norenburg, J., Opresko, D. M., Osawa, M., Paulay, G., Perrin, W., Pilger, J. F., Poore, G. C., Pugh, P., Read, G. B., Reimer, J. D., Rius, M., Rocha, R. M., Saiz-Salinas, J. I., Scarabino, V., Schierwater, B., Schmidt-Rhaesa, A., Schnabel, K. E., Schotte, M., Schuchert, P., Schwabe, E., Segers, H., Self-Sullivan, C., Shenkar, N., Siegel, V., Sterrer, W., Stöhr, S., Swalla, B., Tasker, M. L., Thuesen, E. V., Timm, T., Todaro, M. A., Turon, X., Tyler, S., Uetz, P., van der Land, J., Vanhoorne, B., van Ofwegen, L. P., van Soest, R. W., Vanaverbeke, J., Walker-Smith, G., Walter, T. C., Warren, A., Williams, G. C., Wilson, S. P., and Costello, M. J.: The Magnitude of Global Marine Biodiversity, Curr. Biol., 22, 2189-2202, https://doi.org/10.1016/j.cub.2012.09.036, 2012.

Baldwin, R. J. and Smith Jr., K. L.: Temporal variation in the catch rate, length, color, and sex of the necrophagus amphipod, Eurythenes gryllus, from the central and eastern North Pacific, Deep-Sea Res. Pt. I, 34, 425-439, https://doi.org/10.1016/01980149(87)90146-4, 1987.

Barnard, J. L.: Gammaridean Amphipoda from depth of 400 to 6000 meters, Galathea. Rep., 5, 23-128, 1961.

Barnard, J. L. and Ingram, C.: Lysianassoid Amphipoda (Crustacea) from Deep-Sea Thermal Vents, Smithson Contrib. Zool., 499, 180, 1990.

Barnard, J. L. and Karaman, G.: The Families and Genera of Marine Gammaridean Amphipoda (Except Marine Gammaroids), Rec. Aust. Mus., 13, 1-866, https://doi.org/10.3853/j.08127387.13.1991.367, 1991.

Billett, D. S. M., Lampitt, R. S., Rice, A. L., and Mantoura, R. F. C.: Seasonal sedimentation of phytoplankton to the deep-sea benthos, Nature, 302, 520-522, https://doi.org/10.1038/302520a0, 1983.

Birstein, Y. A. and Vinogradov, M. E.: Pelagischeskie gammaridy tropischeskoi chasti Ticogo Okeana [Pelagic Gammaridea of the tropical part of the Pacific Ocean], Trudy instituta okeanologii Akademi nauk SSSR, 34, 165-241, 1960.

Blankenship, L. E., Yayanos, A. A., Cadien, D. B., and Levin, L. A.: Vertical zonation patterns of scavenging amphipods from the Hadal zone of the Tonga and Kermadec Trenches, Deep-Sea Res. Pt. I., 53, 48-61, https://doi.org/10.1016/j.dsr.2005.09.006, 2006.

Brandt, A., Gooday, A. J., Brix, S. B., Brökeland, W., Cedhagen, T., Choudhury, M., Cornelius, N., Danis, B., De Mesel, I., Diaz, R. J., Gillan, D. C., Ebbe, B., Howe, J., Janussen, D., Kaiser, S., Linse, K., Malyutina, M., Brandao, S., Pawlowski, J., and Raupach, M.: The So Deep Sea: First Insights Into Biodiversity And Biogeography, Nature, 447, 307311, https://doi.org/10.1038/nature05827, 2007.

Brandt, A., Błazewicz-Paszkowycz, M., Bamber, R. N., Mühlenhardt-Siegel, U., Malyutina, M. V., Kaiser, S., De Broyer, C., and Havermans, C.: Are there widespread peracarid species in the deep sea (Crustacea: Malacostraca)?, Pol. Polar Res., 33, 139-162, https://doi.org/10.2478/v10183-012-0012-5, 2012. 
Bray, J. R. and Curtis, J. T.: An ordination of upland forest communities of southern Wisconsin, Ecol. Monogr., 27, 325-349, 1957.

Chevreux, E.: Diagnoses d'amphipodes nouveaux provenant des campagnes de la Princesse-Alice dans l'Atlantique nord, Bull. Inst. océanogr. (Monaco), 117, 1-13, 1908.

Conlan, K. E.: Precopulatory mating behavior and sexual dimorphism in the amphipod Crustacea, Hydrobiologia, 223, 255-282, https://doi.org/10.2307/1942268, 1991.

Delić, T., Trontelj, P., Rendoš, M., and Fišer, C.: The importance of naming cryptic species and the conservation of endemic subterranean amphipods, Sci. Rep.-UK, 7, 3391, https://doi.org/10.1038/s41598-017-02938-z, 2017.

d'Udekem d'Acoz, C. and Havermans, C.: Contribution to the systematics of the genus Eurythenes $\mathrm{S}$. I. Smith in Scudder, 1882 (Crustacea: Amphipoda: Lysianassoidea: Eurytheneidae), Zootaxa, 3971, 67-74, https://doi.org/10.11646/zootaxa.3971.1.1, 2015.

Etter, R. J., Boyle, E. E., Glazier, A., Jennings, R. M., Dutra, E., and Chase, M. R.: Phylogeography of a Pan-Atlantic Abyssal Protobranch Bivalve: Implications for Evolution in the Deep Atlantic, Mol. Ecol., 20, 829-843, https://doi.org/10.1111/j.1365294X.2010.04978.x, 2011.

Futuyma, D. J.: Evolutionary Biology, 3rd Edn., Sinauer Associates, Sunderland, MA, 751 pp., 1998.

Gage, J. D. and Tyler, P. A.: Deep-Sea Biology: a natural history of organisms at the deep-sea floor, Cambridge University Press, Cambridge, https://doi.org/10.1086/417611, 1991.

German, C. R., Ramirez-Llodra, E., Baker, M. C., Tyler, P. A., and the Chess Scientific Steering Committee: Deep-Water Chemosynthetic Ecosystem Research during the Census of Marine Life Decade and Beyond: A Proposed Deep Ocean Road Map, PLoS ONE, 6, 1-16, https://doi.org/10.1371/journal.pone.0023259, 2011.

Glover, A., Paterson, G., Bett, B., Gage, J., Sibuet, M., Sheader, M., and Hawkins, L.: Patterns in polychaete abundance and diversity from the Madeira Abyssal Plain, northeast Atlantic, Deep-Sea Res. Pt. I, 48, 217-236, https://doi.org/10.1016/S09670637(00)00053-4, 2001

Glover, A., Dahlgren, T. G., Wiklund, H., Mohrbeck, I., and Smith, C. R.: An end-to-end DNA taxonomy methodology for benthic biodiversity survey in the Clarion-Clipperton Zone, central Pacific abyss, Journal of Marine Science and Engineering, 4, 1-34, https://doi.org/10.3390/jmse4010002, 2016.

Gotelli, N. J. and Colwell, R. K.: Quantifying Biodiversity: Procedures and Pitfalls in the Measurement and Comparison of Species Richness, Ecol. Lett., 4, 379-391, https://doi.org/10.1046/j.1461-0248.2001.00230.x, 2001

Hannides, A. and Smith, C. R.: The northeast abyssal Pacific plain, in: Biogeochemistry of Marine Systems, edited by: Black, K. B. and Shimmield, G. B., CRC Press, Boca Raton, Florida, 208237, https://doi.org/10.1201/9780367812423-7, 2003.

Havermans, C.: Have we so far only seen the tip of the iceberg? Exploring species diversity and distribution of the giant amphipod Eurythenes, Biodiversity, 17, 12-25, https://doi.org/10.1080/14888386.2016.1172257, 2016.

Havermans, C. and Smetacek, V.: Bottom-up and top-down triggers of diversification: A new look at the evolutionary ecology of scavenging amphipods in the deep sea, Prog. Oceanogr., 164, 37-51, https://doi.org/10.1016/j.pocean.2018.04.008, 2018.
Havermans, C., Sonet, G., d'Udekem d'Acoz, C., Nagy, Z. T., Martin, P., Brix, S., Riehl, T., Agrawal, S., and Held, C.: Genetic and morphological divergences in the cosmopolitan deep-sea amphipod Eurythenes gryllus reveal a diverse abyss and a bipolar species, PLoS ONE, 1-14, e74218, https://doi.org/10.1371/journal.pone.0074218, 2013.

Highsmith, R.: Floating and algal rafting as potential dispersal mechanisms in brooding invertebrates, Mar. Ecol.-Prog. Ser., 25, 169-179, https://doi.org/10.3354/meps025169, 1985.

Hilário, A., Metaxas, A., Gaudron, S. M., Howell, K. L., Mercier, A., Mestre, N. C., Ross, R. E., Thurnherr, A. M., and Young, C.: Estimating dispersal distance in the deep sea: challenges and applications to marine reserves, Front. Mar. Sci., 2, 1-14, https://doi.org/10.3389/fmars.2015.00006, 2015.

Ide, K., Takahashi, K., Nakano, T., Minoru, S., and Omori, M.: Chemoreceptive foraging in a shallow-water scavenging lysianassid amphipod: Role of amino acids in the location of carrion in Scopelocheirus onagawae, Mar. Ecol.-Prog. Ser., 317, 193-202, https://doi.org/10.3354/meps317193, 2006.

Ingram, C. L. and Hessler, R. R.: Distribution and behavior of scavenging amphipods from the central North $\mathrm{Pa}-$ cific, Deep-Sea Res., 30, 683-706, https://doi.org/10.1016/01980149(83)90017-1, 1983.

International Seabed Authority (ISA): Developing a Regulatory Framework for Mineral Exploitation in the Area A Discussion Paper on the Development and Drafting of Regulations on Exploitation for Mineral Resources in the Area, Env. Matt. 1-102, ISA, Kingston, Jamaica, available at https://ran-s3.s3.amazonaws.com/isa.org.jm/s3fs-public/ documents/EN/Regs/DraftExpl/DP-EnvRegsDraft25117.pdf (last access: 18 April 2020), 2017.

Kankaanpää, H., Laurén, M., Mattson, M., and Lindström, M.: Effects of bleached kraft mill effluents on the swimming activity of Monoporeia affinis (Crustacea, Amphipoda) lindström, Chemosphere, 31, 4455-4473, https://doi.org/10.1016/00456535(95)00325-3, 1995.

Laver, M. B., Olsson, M. S., Edelman, J. L., and Smith Jr., K. L.: Swimming rates of scavenging deep-sea amphipods recorded with a free-vehicle video camera, Deep-Sea Res. Pt. II, 32, 1135 1142, https://doi.org/10.1016/0198-0149(85)90067-6, 1985.

Lester, S. E., Ruttenberg, B. I., Gaines, S. D., and Kinlan, B. P.: The relationship between dispersal ability and geographic range size, Ecol. Lett., 10, 745-758, https://doi.org/10.1111/j.14610248.2007.01070.x, 2007.

Levin, L. A., Etter, R. J., Rex, M. A., Gooday, A. J., Smith, C. R., Pineda, J., Stuart, C. T., Hessler, R. R., and Pawson, D.: Environmental influences on regional deepsea species diversity, Annu. Rev. Ecol. Evol. S., 32, 5193, https://doi.org/10.1146/annurev.ecolsys.32.081501.114002, 2001.

Liow, L. H.: Does versatility as measured by geographic range, bathymetric range and morphological variability contribute to taxon longevity? Global Ecol. Biogeogr., 16, 117-128, https://doi.org/10.1111/j.1466-8238.2006.00269.x, 2007.

Lodge, M., Johnson, D., Le Gurun, G., Wengler, M., Weaver, P., and Gunn, V.: Seabed mining: International Seabed Authority environmental management plan for the ClarionClipperton Zone. A partnership approach, Mar. Policy, 49, 6672, https://doi.org/10.1016/j.marpol.2014.04.006, 2014. 
Lonsdale, P.: Clustering of suspension-feeding macrobenthos near abyssal hydrothermal vents at oceanic spreading centres, Deep-Sea Res., 24, 857-863, https://doi.org/10.1016/01466291(77)90478-7, 1977.

Lörz, A.-N., Jażdżewska, A. M., and Brandt, A.: A new predator connecting the abyssal with the hadal in the Kuril-Kamchatka Trench, NW Pacific, PeerJ, 6, e4887, https://doi.org/10.7717/peerj.4887, 2018.

McClain, C. and Hardy, S.: The dynamics of biogeographic ranges in the deep sea, Proc. Biol. Sci. Proc. Royal Soc., 277, 35333546, https://doi.org/10.1098/rspb.2010.1057, 2010.

Narahara-Nakano, Y., Nakano, T., and Tomikawa, K.: Deepsea amphipod genus Eurythenes from Japan, with a description of a new Eurythenes species from off Hokkaido (Crustacea: Amphipoda: Lysianassoidea), Mar. Biodivers., 18671616, https://doi.org/10.1007/s12526-017-0758-4, 2017.

OBIS (Ocean Biogeographic Information System): available at: https://obis.org/, last access: 12 January 2019.

Patel, T.: Scavenging amphipod abundances at baited trap stations, collected during SONNE cruises SO239 and SO242/1, ClarionClipperton Fracture Zone (NE Pacific) and DisCOL Experimental Area (Peru Basin), PANGAEA, https://doi.pangaea.de/10. 1594/PANGAEA.914677, 2020.

Paull, C. K., Hecker, B., Commeau, R., Freeman-Lynde, R. P., Neumann, C., Corso, W. P., Golubic, S., Hook, J. E., Sikes, E., and Curray, J.: Biological communities at the Florida escarpment resemble hydrothermal vent taxa, Science, 226, 965-967, https://doi.org/10.1126/science.226.4677.965, 1984.

Pfeffer, G.: Die Krebse von Sud-Georgien nach der Ausbeute der Deutschen Station 1882-83. 2.Teil, Die Amphipoden Jahrbuch der Hamburgischen Wissenschaftlichen Anstalten, 5, 75-142, 1888.

Premke, K., Muyakshin, S., Klages, M., and Wegner, J.: Evidence for long-range chemoreceptive tracking of food odour in deepsea scavengers by scanning sonar data, J. Exp. Mar. Biol. Ecol., 285, 283-294, https://doi.org/10.1016/S0022-0981(02)00533-6, 2003.

Ramirez-Llodra, E., Brandt, A., Danovaro, R., De Mol, B., Escobar, E., German, C. R., Levin, L. A., Martinez Arbizu, P., Menot, L., Buhl-Mortensen, P., Narayanaswamy, B. E., Smith, C. R., Tittensor, D. P., Tyler, P. A., Vanreusel, A., and Vecchione, M.: Deep, diverse and definitely different: unique attributes of the world's largest ecosystem, Biogeosciences, 7, 2851-2899, https://doi.org/10.5194/bg-7-2851-2010, 2010.

Ramirez-Llodra, E., Tyler, P. A., Baker, M. C., Bergstad, O. A., Clark, M. R., and Escobar, E.: Man and the last great wilderness: human impact on the Deep Sea, PLoS ONE, 6, e2258, https://doi.org/10.1371/journal.pone.0022588, 2011.

R Core Team: R: A language and environment for statistical computing. R Foundation for Statistical Computing, Vienna, Austria, ISBN 3-900051-07-0, available at: http://www.R-project. org/ (last access: 25 June 2018), 2013.

Rex, M. A., Stuart, C. T., Hessler, R., Allen, J. A., Sanders, H. L., and Wilson, G. D. F.: Global-scale latitudinal patterns of species diversity in the deep-sea benthos, Nature, 365, 636-639, https://doi.org/10.1038/365636a0, 1993.

Ritchie, H., Jamieson, A. J., and Piertney, S. B.: Isolation and Characterization of Microsatellite DNA Markers in the Deep-Sea Amphipod Paralicella tenuipes by Illumina MiSeq Sequencing,
J. Hered., 107, 367-371, https://doi.org/10.1093/jhered/esw019, 2016.

Sanders, H. L.: Marine benthic diversity: a comparative study, Am. Nat., 102, 243-282, https://doi.org/10.1086/282541, 1968.

Schellenberg, A.: Die abyssale und pelagische Gammariden, Bull. Mus. Comp. Zool., 69, 191-201, 1929.

Schön, I., Pinto, R. L., Halse, S., Smith, A. J., and Martens, K.: Cryptic Species in Putative Ancient Asexual Darwinulids (Crustacea, Ostracoda), PLoS ONE, 7, e39844, https://doi.org/10.1371/journal.pone.0039844, 2012.

Schulenberger, E. and Barnard, J. L.: Clarification of the Abyssal Amphipod, Paralicella tenuipes Chevreux, Crustaceana, 31, 267274, https://doi.org/10.1163/156854076X00053, 1976.

Schüller, M. and Ebbe, B.: Global distributional patterns of selected deep-sea Polychaeta (Annelida) from the Southern Ocean, Deep-Sea Res. Pt. II, 54, 1737-1751, https://doi.org/10.1016/j.dsr2.2007.07.005, 2007.

Seefeldt, M. A., Weigand, A. M., Havermans, C., Moreira, E., and Held, C.: Fishing for scavengers: an integrated study to amphipod (Crustacea: Lysianassoidea) diversity of Potter Cove (South Shetland Islands, Antarctica), Mar. Biodivers., 48, 2081-2104, https://doi.org/10.1007/s12526-017-0737-9, 2018.

Simpson, E. H.: Measurement of diversity, Nature, 163, 688, https://doi.org/10.1038/163688a0, 1949.

Smith, C. R. and Demopoulos, A. W. J.: Ecology of the deep Pacific Ocean floor, in: Ecosystems of the World Volume 28: Ecosystems of the Deep Ocean, edited by: Tyler, P. A., Elsevier, Amsterdam, 179-218, 2003.

Smith, C. R., Kukert, H., Wheatcroft, R. A., Jumars, P. A., and Deming, J. W.: Vent fauna on whale remains, Nature, 341, 27-28, https://doi.org/10.1038/341027a0, 1989.

Smith, C. R., Drazen, J., and Mincks, S. L.: Deep-sea Biodiversity and Biogeography: Perspectives from the Abyss, International Seabed Authority Seamount Biodiversity Symposium, 113, 2006.

Sweetman, A. K., Thurber, A. R., Smith, C. R., Levin, L. A., Mora, C., Wei, C.-L., Gooday, A. J., Jones, D. O. B., Rex, M., Yasuhara, M., Ingels, J., Ruhl, H. A., Frieder, C. A., Danovaro, R., Würzberg, L., Baco, A., Grupe, B. M., Pasulka, A., Meyer, K. S., Dunlop, K. M., Henry, L.-A., and Roberts, J. M.: Major impacts of climate change on deep-sea benthic ecosystems, Elem. Sci. Anth., 5, 4, https://doi.org/10.1525/elementa.203, 2017.

Taguchi, Y. H. and Oono, Y.: Relational patterns of gene expression via non-metric multidimensional scaling analysis, Bioinformatics, 21, 730-740, https://doi.org/10.1093/bioinformatics/bti067, 2005.

Thiel, H.: Deep-sea Environmental Disturbance and Recovery Potential, Int. Rev. Ges. Hydrobio., 77, 331-339, https://doi.org/10.1002/iroh.19920770213, 1992.

Thurston, M. H.: Abyssal necrophagous amphipods (Crustacea: Amphipoda) in the northeast and tropical Atlantic Ocean, Prog. Oceanogr., 24, 257-274, https://doi.org/10.1016/00796611(90)90036-2, 1990

Vader, W.: How many amphipods species?, 6th International Crustacean Congress, Glasgow, Scotland, 18-22 July 2005, 143 pp., 2005. 